\title{
Pd/C-Mediated synthesis of indoles in water
}

\author{
Mohosin Layek $^{1,2}$, Udaya Lakshmi ${ }^{1}$, Dipak Kalita ${ }^{1}$, Deepak K. Barange ${ }^{1}$, \\ Aminul Islam ${ }^{1}$, K. Mukkanti ${ }^{2}$ and Manojit Pal ${ }^{*}, 3,4$
}

\section{Full Research Paper}

\section{Address:}

${ }^{1}$ Dr. Reddy's Laboratories Ltd, Bollaram Road, Miyapur, Hyderabad 500049 , India, ${ }^{2}$ Chemistry Division, Institute of Science and Technology, JNT University, Kukatpally, Hyderabad 500072, India, ${ }^{3}$ New Drug Discovery, R\&D Center, Matrix Laboratories Ltd., Anrich Industrial Estate, Bollaram, Jinnaram Mandal, Medak District, Andra Pradesh 502 325, India and ${ }^{4}$ (present address:) Institute of Life Science, University of Hyderabad Campus, Gachibowli, Hyderabad 500 046, Andhra Pradesh, India

\section{Email:}

Manojit Pal ${ }^{*}$ - manojitpal@rediffmail.com

* Corresponding author

Keywords:

C-C bond; charcoal; copper; indoles; palladium
Beilstein Journal of Organic Chemistry 2009, 5, No. 46 doi: $10.3762 /$ bjoc. 5.46

Received: 12 July 2009

Accepted: 09 September 2009

Published: 23 September 2009

Associate Editor: I. Marek

(C) 2009 Layek et al; licensee Beilstein-Institut. License and terms: see end of document.

\begin{abstract}
We describe the utility of a Pd/C-Cu mediated method in the synthesis of 2,5-disubstituted indoles in water via a coupling-cyclization strategy. Further application of this methodology has been demonstrated in the preparation of a target indole derivative via a 7-step process the key step being the $\mathrm{Pd} / \mathrm{C}$-mediated coupling reaction.
\end{abstract}

\section{Introduction}

2-Substituted indoles (A, Figure 1) display a wide range of pharmacological activities and therefore have been explored as a number of potential therapeutic agents [1] e.g. inhibitors of proteases involved in coagulation [2,3], antagonists of G-protein-coupled receptors [4,5], anti-angiogenic compounds [6] and inhibitors of endothelinconverting-enzyme [7]. 5-Alkyl substituted indoles e.g. naratriptan (B, Figure 1) on the other hand have been reported as a $5-\mathrm{HT}_{1 \mathrm{~B} / 1 \mathrm{D}}$ receptor agonists for the potential treatment of migraine headache [8]. Thus a combination of both in a single molecule was expected to provide novel agent $(\mathbf{C}$, Figure 1$)$ of potential biological significance. Due to our continued interest in the development of indole based compound libraries we decided to synthesize compound $\mathbf{C}$ and its analogues.

A large number of methods [9-12] have been reported for the construction of indole ring many of which are mediated by transition metal catalysts. Among these methods palladium mediated protocols have gain considerable interest [13]. In our effort towards the development of palladium-catalyzed reactions in aqueous media, we have reported an efficient synthesis of 2-substituted indoles via a Pd/C-catalyzed coupling-cyclization process in water [14]. Herein, we report a further continuation of our previous work towards the synthesis of a variety of 


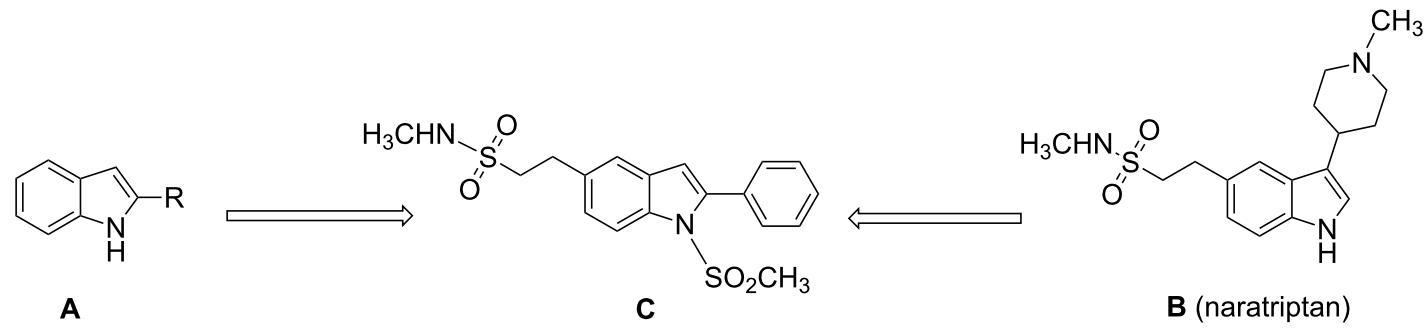

Figure 1: Design of novel indole derivative $\mathbf{C}$ of pharmacological interest.

indole derivatives along with the preparation of target compound $\mathbf{C}$.

\section{Results and Discussion}

In our previous study after examining a number of $\mathrm{N}$-substituted $o$-iodoanilides we have observed that the $N$-methanesulfonyl derivative provided the best result in terms of product nature and yields [14]. However, the presence of only one substituent, i.e. a methyl group on the $o$-iodoaniline ring was examined. Moreover, the presence of other sulfonyl groups e.g. the benzenesulfonyl moiety on the aniline nitrogen was not studied. In the present study we aimed to conduct further research taking into account of above-mentioned aspects. Thus, when $o$-iodoanilide 1 was treated with terminal alkyne 2 (3.0 equiv) in water in the presence of $10 \% \mathrm{Pd} / \mathrm{C}$ (0.03 equiv), $\mathrm{PPh}_{3}$ ( 0.12 equiv), $\mathrm{CuI}$ ( 0.06 equiv) and 2 -aminoethanol ( 3.0 equiv) under nitrogen, 2-substituted indoles $\mathbf{3}$ were obtained in good yields (Scheme 1). The details of this study are summarized in Table 1.

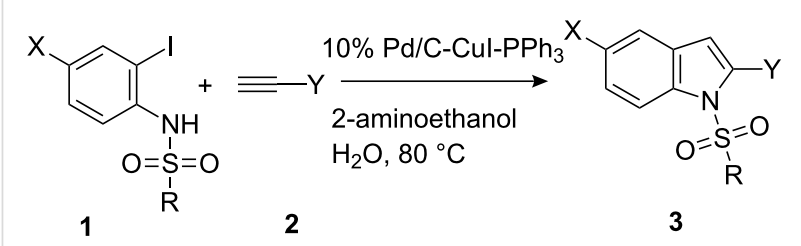

$\mathrm{X}=\mathrm{F}, \mathrm{Cl}, \mathrm{Et} ; \mathrm{R}=\mathrm{Ms}, \mathrm{Ts}$

Scheme 1: Preparation of 2,5-disubstituted indole.

We have examined four anilides 1a-d each of which participated well in the present $\mathrm{Pd} / \mathrm{C}$-mediated coupling-cyclization process. Substituents such as halogen atoms (1a, 1c and 1d) and alkyl groups (1b) on the aryl ring were well tolerated. A range of terminal alkynes 2 were employed in the present reaction to obtain the corresponding indole 3 in $65-90 \%$ yield via a single step method. Thus, we have extended the generality and scope of our previously reported method considerably demonstrating its potential in the synthesis of a diversity based indole library.
In our previous [14] as well as the present study we have used three equivalents of terminal alkynes to obtain the optimum yields of products. It is possible that the excess equivalents of terminal alkynes might undergo dimerization via oxidative coupling though no significant amount of 1,3-butadiyne derivative was isolated as a side product from any of the reactions presented in Table 1. However, to assess the effect of using fewer equivalents of terminal alkynes we conducted an experiment using $\mathbf{1 a}$ and $\mathbf{2 a}$ in a ratio of 1.0:1.2 without changing the other reaction conditions. The desired indole $\mathbf{3 a}$ was isolated in $60 \%$ yield (vs $79 \%$ of entry 1 , Table 1 ) confirming the requirement for an excess amount of terminal alkyne to achieve the best yield of the desired product.

We have also examined the use of a basic iodoaniline such as $\mathrm{N}$-methyl substituted 2-iodoaniline in the present coupling reaction with terminal alkynes. Isolation of 2-alkynyl substituted $\mathrm{N}$-methylaniline as a sole product rather than expected indole indicated that the presence of an electron donating group on the nitrogen was unfavourable for the cyclization step though the $\mathrm{C}-\mathrm{C}$ coupling reaction proceeded well under the conditions employed.

Having prepared a variety of $N$-substituted indole derivatives successfully we then undertook the synthesis of the target indole $\mathbf{C}$. Compound $\mathbf{C}$ was prepared from bromo compound $\mathbf{4}$ following a 7-step process using the $\mathrm{Pd} / \mathrm{C}$-mediated indole synthesis as a key step as shown in Scheme 2. Thus treatment of bromide 4 with $\mathrm{Na}_{2} \mathrm{SO}_{3}$ provided corresponding sulfonic acid 5 which on treating with $\mathrm{PCl}_{5}$ provided the sulfonyl chloride derivative 6. On reaction with aqueous methylamine compound 6 provided the methanesulfonamide derivative 7 , the nitro group of which was reduced in the presence of Raney nickel to yield the corresponding aniline derivative $\mathbf{8}$. Iodination of $\mathbf{8}$ using elemental iodine provided the $o$-iodoaniline derivative 9 which was converted to the corresponding methanesulfonamide 10. Compound $\mathbf{1 0}$ when reacted with phenylacetylene in the presence of $10 \% \mathrm{Pd} / \mathrm{C}$-CuI- $\mathrm{PPh}_{3}$ and 2-aminoethanol in water provided the desired indole derivative $\mathbf{C}$. 
Table 1: Pd/C-Catalyzed synthesis of 2,5-disubstituted $N$-sulfonyl-indoles in aqueous media. ${ }^{a}$

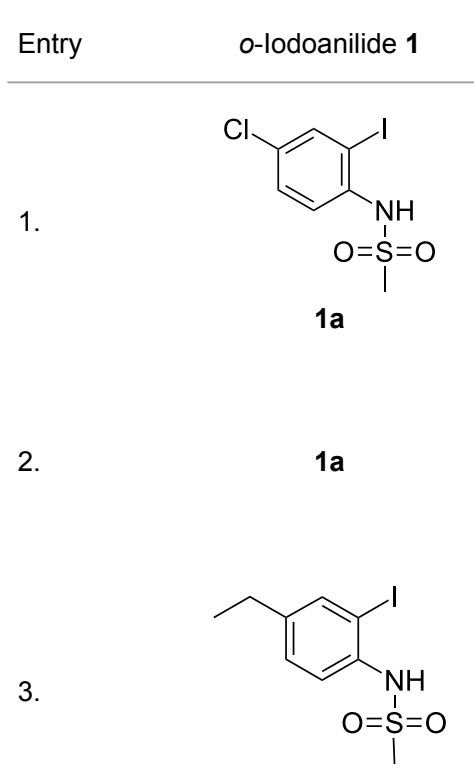

$1 \mathrm{~b}$

4.

$1 \mathrm{~b}$

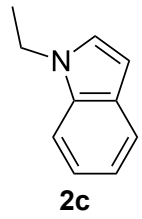

5.<smiles>CS(=O)(=O)Nc1ccc(F)cc1I</smiles>

$1 c$
Alkyne 2; $\mathrm{Y}=$
$\underset{2 \mathrm{a}}{-\mathrm{CH}_{2} \mathrm{CH}(\mathrm{OH}) \mathrm{CH}_{3}}$

$-\mathrm{C}_{6} \mathrm{H}_{4} \mathrm{CH}_{3}-p$

$2 b$

2b

Time (h)

Product $3^{b}$

Yield (\%)

10<smiles>CC(O)Cc1cc2cc(Cl)ccc2n1S(C)(=O)=O</smiles>

3a<smiles>Cc1ccc(-c2cc3cc(Cl)ccc3n2S(C)(=O)=O)cc1</smiles>

3b<smiles>CCc1ccc2c(c1)cc(-c1ccc(C)cc1)n2S(C)(=O)=O</smiles>

$3 c$<smiles>CCc1ccc2c(c1)cc(Cn1ccc3ccccc31)n2S(C)(=O)=O</smiles>

3d<smiles>Cc1ccc(-c2cc3cc(F)ccc3n2S(C)(=O)=O)cc1</smiles>

$3 e$<smiles>CS(=O)(=O)n1c(Cn2ccc3cc(OCc4ccccc4)ccc32)cc2cc(F)ccc21</smiles>

3f<smiles>Cc1ccc(S(=O)(=O)n2c(Cn3ccc4ccccc43)cc3cc(F)ccc32)cc1</smiles>

86

78

76

7.

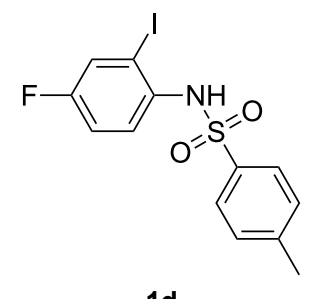

1d
14<smiles>CCn1ccc2cc(OCc3ccccc3)ccc21</smiles>

2c

10 
Table 1: Pd/C-Catalyzed synthesis of 2,5-disubstituted $N$-sulfonyl-indoles in aqueous media. ${ }^{\text {a }}$ (continued)

8.

1d

$-\left(\mathrm{CH}_{2}\right)_{3} \mathrm{OH}$

$2 \mathrm{e}$

14<smiles>OCCCc1cc2cc(F)ccc2[nH]1</smiles>

$\mathrm{O}=\mathrm{S}=\mathrm{O}$<smiles>Cc1ccc(C)cc1</smiles>

$3 \mathrm{~h}$<smiles>CC(O)Cc1cc2cc(F)ccc2[nH]1</smiles>

12

2a

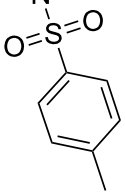

$3 \mathbf{i}$<smiles>CC(C)(O)c1cc2cc(F)ccc2[nH]1</smiles>

$\mathrm{O}=\mathrm{S}=0$

1

10

2c

14<smiles>CS(=O)(=O)n1c(Cn2ccc3ccccc32)cc2cc(F)ccc21</smiles>

3k

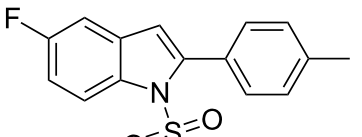

10<smiles>Cc1ccc(S(=O)(=O)[O-])cc1</smiles>

3I<smiles>O=Cn1c(-c2ccccc2)cc2cc(F)ccc21</smiles>

8
78

80

$3 m$ 
Table 1: $\mathrm{Pd} / \mathrm{C}$-Catalyzed synthesis of 2,5-disubstituted $N$-sulfonyl-indoles in aqueous media. ${ }^{\text {a }}$ (continued)

14.

$1 d$<smiles>CCN1C(=O)c2ccccc2C1=O</smiles>

2h

1d

$-\left(\mathrm{CH}_{2}\right)_{3} \mathrm{CH}_{3}$

2i

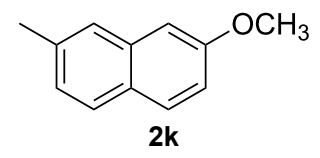

$-\left(\mathrm{CH}_{2}\right)_{3} \mathrm{Cl} 2$

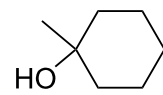

$2 \mathrm{~m}$<smiles>Cc1ccc(S(=O)(=O)n2c(CN3C(=O)c4ccccc4C3=O)cc3cc(F)ccc32)cc1</smiles>

$3 n$<smiles>CCCCc1cc2cc(F)ccc2[nH]1</smiles>

12<smiles>Cc1ccc(S(C)(=O)=O)cc1</smiles>

74

78

24<smiles>CS(=O)(=O)n1c(-c2ccccc2[N+](=O)[O-])cc2cc(F)ccc21</smiles>

$3 p$<smiles>COc1ccc2ccc(-c3cc4cc(F)ccc4n3S(C)(=O)=O)cc2c1</smiles>

$3 q$<smiles>CS(=O)(=O)n1c(CCCCl)cc2cc(F)ccc21</smiles>

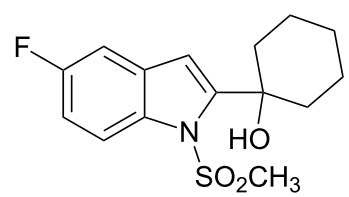

74

78

85

aAll reactions were carried out by using 1 (1.0 equiv), 2 (3.0 equiv), 1:4:2 ratio of $\mathrm{Pd} / \mathrm{C}: \mathrm{PPh}_{3}: \mathrm{Cul}_{\text {, }}$ 2-aminoethanol (3.0 equiv) in $\mathrm{H}_{2} \mathrm{O}$. bIdentified by ${ }^{1} \mathrm{H}$ NMR, ${ }^{13} \mathrm{C}$ NMR, IR, MS.

Clsolated yields. 


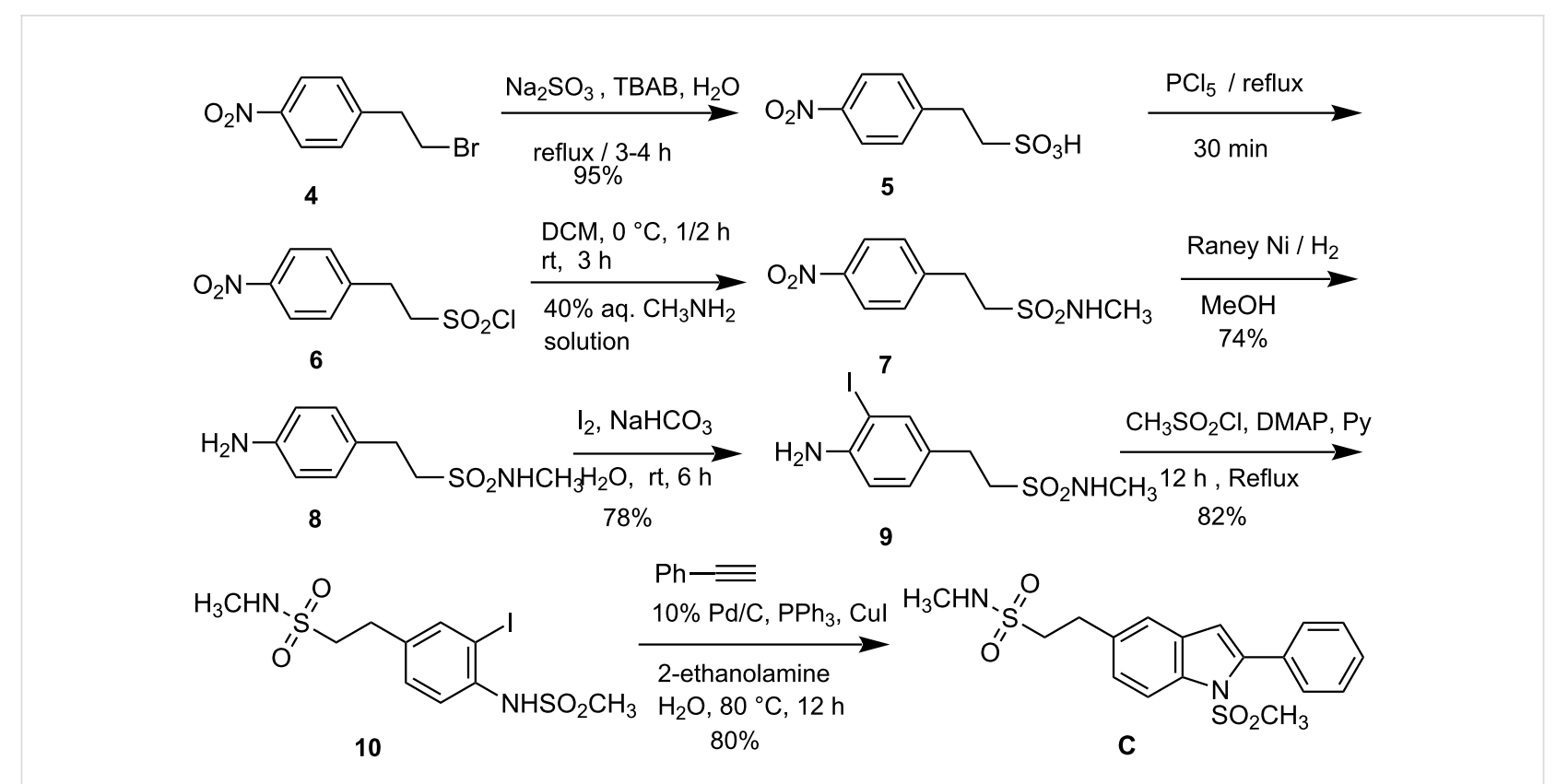

Scheme 2: Preparation of compound C.

\section{Conclusions}

In conclusion, we have demonstrated the potential of our previously reported palladium on carbon mediated practical synthesis of 2-substituted indoles in water. Besides preparing a wide variety of indole derivatives the methodology was utilized to prepare one of our target indole derivatives smoothly. We believe that the present demonstration would encourage organic/medicinal chemists to explore the utility of this methodology for easy access to indole based agents of pharmaceutical interest.

\section{Experimental}

General methods: Unless stated otherwise, reactions were monitored by thin layer chromatography (TLC) on silica gel plates $\left(60 \mathrm{~F}_{254}\right)$, visualizing with ultraviolet light or iodine spray. Flash chromatography was performed on silica gel (60-120 mesh) using distilled petroleum ether and ethyl acetate. ${ }^{1} \mathrm{H}$ and ${ }^{13} \mathrm{C}$ NMR spectra were determined either in $\mathrm{CDCl}_{3}$ or DMSO- $d_{6}$ solution using 400 and $50 \mathrm{MHz}$ spectrometers, respectively. Proton chemical shifts $(\delta)$ are relative to tetramethylsilane (TMS, $\delta=0.0$ ) as internal standard and expressed in parts per million. Spin multiplicities are given as s (singlet), $d$ (doublet), $\mathrm{t}$ (triplet), and $\mathrm{m}$ (multiplet) as well as b (broad). Coupling constants $(J)$ are given in hertz. Infrared spectra were recorded on a FTIR spectrometer. Melting points were determined by using thermal analysis and differential scanning calorimetry (DSC) was generated with the help of DSC-60A dector. MS spectra were obtained on a mass spectrometer. Chromatographic (HPLC) purity was determined by using area normaliz- ation method and the condition specified in each case: column, mobile phase (range used), flow rate, detection wavelength, and retention times. All the reagents used are commercially available.

\section{General method for the preparation of o-iodoanilides (1a-d)}

Step A (a typical procedure): A suspension of 4-fluoro aniline $(5.0 \mathrm{~g}, 0.045 \mathrm{~mol})$ in aqueous solution $(50.0 \mathrm{~mL})$ of sodium bicarbonate $(0.045 \mathrm{~mol})$ was stirred for $0.5 \mathrm{~h}$. Then iodine $(0.040 \mathrm{~mol})$ was added at $5-10{ }^{\circ} \mathrm{C}$ and the mixture was stirred for $12.0 \mathrm{~h}$. After completion, the reaction mixture was diluted with ethyl acetate $(250 \mathrm{~mL})$ and extracted with ethyl acetate (3 $\times 250 \mathrm{~mL}$ ). The organic layers were collected, combined, washed with saturated aqueous sodium thiosulfate solution $(2 \times$ $125 \mathrm{~mL}$ ), dried over anhydrous $\mathrm{Na}_{2} \mathrm{SO}_{4}$ and concentrated under vacuum. The crude product was purified by column chromatography on silica gel using $3: 1$, hexanelethyl acetate to afford the desired product ( $6.4 \mathrm{~g}, 60 \%$ yield). 4-chloro-2-iodoaniline [15]: white solid, mp $42-43{ }^{\circ} \mathrm{C}$; ${ }^{1} \mathrm{H}$ NMR $\left(\mathrm{CDCl}_{3}, 400 \mathrm{MHz}\right) \delta 7.59$ $(\mathrm{d}, J=2.2 \mathrm{~Hz}, 1 \mathrm{H}), 7.08(\mathrm{dd}, J=8.6,2.2 \mathrm{~Hz}, 1 \mathrm{H}), 6.62(\mathrm{~d}, J=$ $8.6 \mathrm{~Hz}, 1 \mathrm{H}), 4.19$ (br s, $\left.\mathrm{NH}_{2}\right) ; \mathrm{m} / \mathrm{z}$ (ES Mass) $253(\mathrm{M}+1$, $100 \%$ ) IR ( $\left.\mathrm{cm}^{-1}, \mathrm{KBr}\right) 3370,1475,1215,1140$. 4-ethyl-2iodoaniline [16]: white solid, mp $38-41{ }^{\circ} \mathrm{C}$; ${ }^{1} \mathrm{H} \mathrm{NMR}\left(\mathrm{CDCl}_{3}\right.$, $400 \mathrm{MHz}) \delta 7.45(\mathrm{~m}, 1 \mathrm{H}), 6.95(\mathrm{~m}, 1 \mathrm{H}), 6.66(\mathrm{~d}, J=8.0 \mathrm{~Hz}$, 1H), 3.85 (br s, $\left.\mathrm{NH}_{2}\right), 2.58(\mathrm{~m}, 2 \mathrm{H}), 1.25$ (s, 3H); m/z (ES Mass) $247(\mathrm{M}+1,100 \%)$; IR ( $\left.\mathrm{cm}^{-1}, \mathrm{KBr}\right) 3347,1480,1333$, 1130. 4-fluoro-2-iodoaniline [17]: Orange oil; ${ }^{1} \mathrm{H} \mathrm{NMR}\left(\mathrm{CDCl}_{3}\right.$, $400 \mathrm{MHz}) \delta 7.35$ (dd, $J=7.9,2.2 \mathrm{~Hz}, 1 \mathrm{H}), 6.90-6.85$ (m, 1H), 
6.68-6.65 (m, 1H), $3.92\left(\right.$ br s, $\left.\mathrm{NH}_{2}\right) ; \mathrm{m} / \mathrm{z}$ (ES Mass) $237(\mathrm{M}+1$, $100 \%) ; 3354,1471,1213,1135$.

Step B (a typical procedure): A mixture of 4-fluoro-2-iodo aniline $(6.4 \mathrm{~g}, 0.027 \mathrm{~mol})$, DMAP $(0.49 \mathrm{~g}, 0.004 \mathrm{~mol})$ was dissolved in pyridine $(50.0 \mathrm{~mL})$ and cooled to $0-5{ }^{\circ} \mathrm{C}$. To this was added methanesulfonyl chloride $(4.0 \mathrm{~g}, 0.035 \mathrm{~mol})$ dropwise and the mixture was refluxed for $12 \mathrm{~h}$. After completion of the reaction, the mixture was cooled to $5-10{ }^{\circ} \mathrm{C}$, neutralized with dil $\mathrm{HCl}$ and extracted with ethyl acetate $(3 \times 300 \mathrm{~mL})$. The organic layers were collected, combined, washed with saturated aq. $\mathrm{NaCl}(2 \times 250 \mathrm{~mL})$, dried over anhydrous $\mathrm{Na}_{2} \mathrm{SO}_{4}$ and concentrated under vacuum. The crude compound was purified by column chromatography on silica gel using $4: 1$ hexanelethyl acetate to afford the desired product $(5.1 \mathrm{~g}, 60 \%$ yield) as a brown solid,

$N$-(4-chloro-2-iodophenyl)methanesulfonamide [18] (1a): White solid, mp $111{ }^{\circ} \mathrm{C}$; $\mathrm{H}$ NMR $\left(\mathrm{CDCl}_{3}, 400 \mathrm{MHz}\right) \delta$ 7.76-7.85 (m, 2H), 7.06-7.11 (m, 1H), 6.51 (br s, 1H), 3.15 (s, $3 \mathrm{H}) ; \mathrm{m} / \mathrm{z}$ (ES Mass) 331 (M+1, 100\%); 3255, 1480, 1335, 1165.

$N$-(4-ethyl-2-iodophenyl)methanesulfonamide (1b): White solid, mp $103{ }^{\circ} \mathrm{C} ;{ }^{1} \mathrm{H}$ NMR $\left(\mathrm{CDCl}_{3}, 400 \mathrm{MHz}\right) \delta 7.65$ (d, $J=$ $2.0 \mathrm{~Hz}, 1 \mathrm{H}), 7.53(\mathrm{~d}, J=8.2 \mathrm{~Hz}, 1 \mathrm{H}), 7.19(\mathrm{dd}, J=8.0$ and 2.0 $\mathrm{Hz}, 1 \mathrm{H}), 6.50$ (br s, 1H), 2.98 (s, 3H) 2.57 (q, $J=7.6,2 \mathrm{H}), 1.20$ (t, $J=7.6,3 \mathrm{H}) ; \mathrm{m} / \mathrm{z}$ (ES Mass) $325(\mathrm{M}+1,100 \%)$; IR $\left(\mathrm{cm}^{-1}\right.$, KBr) 3248, 1486, 1323, 1148.

$\mathrm{N}$-(4-fluoro-2-iodophenyl)methanesulfonamide (1c): Brown solid, mp $91{ }^{\circ} \mathrm{C}$; ${ }^{1} \mathrm{H}$ NMR $\left(\mathrm{CDCl}_{3}, 400 \mathrm{MHz}\right) \delta$ 7.55-7.65 (m, 2H), 7.10-7.15 (m, 1H), 6.47 (br s, 1H), 2.99 (s, 3H); m/z (ES Mass) 315 (M+1, 100\%); 3254, 1481, 1330, 1155.

$N$-(4-fluoro-2-iodophenyl)benzenesulfonamide [17] (1d): Brown solid, mp $99{ }^{\circ} \mathrm{C} ;{ }^{1} \mathrm{H}$ NMR $\left(\mathrm{CDCl}_{3}, 400 \mathrm{MHz}\right) \delta$ 7.57-7.66 (m, 3H), 7.35-7.38 (m, 1H), 7.21-7.26 (m, 2H), 7.04-7.09 (m, 1H), 6.60 (br s, 1H), 2.39 (s, 3H); m/z (ES Mass) 377 (M+1, 100\%); IR ( $\left.\mathrm{cm}^{-1}, \mathrm{KBr}\right) 3254,1478,1337,1167$.

\section{General method for the preparation of 2-substituted indoles 3}

A mixture of 1c (300 mg, $0.95 \mathrm{mmol}), 10 \% \mathrm{Pd} / \mathrm{C}(31.28 \mathrm{mg}$, $0.029 \mathrm{mmol}), \mathrm{PPh}_{3}(29.9 \mathrm{mg}, 0.11 \mathrm{mmol}), \mathrm{CuI}(10.87 \mathrm{mg}$, $0.057 \mathrm{mmol})$ and 2-aminoethanol $(2.85 \mathrm{mmol})$ in $\mathrm{H}_{2} \mathrm{O}(8 \mathrm{~mL})$ was stirred at $25{ }^{\circ} \mathrm{C}$ for $1 \mathrm{~h}$ under nitrogen. The acetylenic compound 2 ( $2.85 \mathrm{mmol})$ was added slowly to the mixture with stirring. The reaction mixture was then stirred at $80{ }^{\circ} \mathrm{C}$ for the time indicated in Table 1. The mixture was cooled to room temperature, diluted with EtOAc $(120 \mathrm{~mL})$ and filtered through celite. The filtrate was collected, washed with cold water $(2 \times$
$75 \mathrm{~mL}$ ), dried over $\mathrm{Na}_{2} \mathrm{SO}_{4}$, filtered and concentrated under vacuum. The residue thus obtained was purified by column chromatography (hexane/EtOAc) to afford the desired product.

Preparation of 2-(4-nitro-phenyl)-ethanesulfonic acid (5): A mixture of 2-(4-nitro-phenyl)ethylbromide $(2.5 \mathrm{~g}, 11.0 \mathrm{mmol})$, sodium sulfite $(2.05 \mathrm{~g}, 16.0 \mathrm{mmol})$ and TBAB $(0.116 \mathrm{~g}, 0.36$ $\mathrm{mmol}$ ) in water was refluxed for $3 \mathrm{~h}$. The reaction mass was cooled to room temperature and washed with ethyl acetate (5 $\mathrm{mL})$. The aqueous layer was acidified $(\mathrm{pH} \sim 2)$ with dil $\mathrm{HCl}$ and concentrated. The gummy residue obtained was treated with methanol $(10 \mathrm{~mL})$ and stirred for $0.5 \mathrm{~h}$. It was then filtered and the filtrate concentrated to give the crude product $(2.4 \mathrm{~g}, 95 \%$ yield); brown liquid, $R_{\mathrm{f}}\left(80 \%\right.$ ethyl acetate $/ n$-hexane) $0.3 ;{ }^{1} \mathrm{H}$ NMR (DMSO- $\left.d_{6}, 400 \mathrm{MHz}\right) \delta 8.15(\mathrm{~d}, J=8.4 \mathrm{~Hz}, 2 \mathrm{H}), 7.30$ (d, $J=8.4 \mathrm{~Hz}, 2 \mathrm{H}), 3.21(\mathrm{bs}, \mathrm{OH}, 1 \mathrm{H}), \mathrm{IR}\left(\mathrm{cm}^{-1}, \mathrm{KBr}\right): 3411$, 1312,$1145 ; \mathrm{m} / \mathrm{z}(\mathrm{ESMS}) 232(\mathrm{M}+1,100 \%) ;{ }^{13} \mathrm{C} \mathrm{NMR}$ $\left(\mathrm{DMSO}-d_{6}, 50 \mathrm{MHz}\right) \delta 146.5,145.2,128.2(2 \mathrm{C}), 123.5$ (2C), $58.5,29.5$; HRMS (ESI): calcd for $\mathrm{C}_{8} \mathrm{H}_{10} \mathrm{NO}_{5} \mathrm{~S}(\mathrm{M}+\mathrm{H})^{+}$ 232.0278 , found 232.0275 .

Preparation of 2-(4-nitro-phenyl)ethanesulfonic acid methylamide (7): Compound 5 (3.70 g, $16.0 \mathrm{mmol}$ ) was cooled and $\mathrm{PCl}_{5}(8.30 \mathrm{~g}, 40.0 \mathrm{mmol})$ was added under anhydrous conditions. The mixture was slowly heated to reflux with stirring for $30 \mathrm{~min}$. The reaction mixture was cooled to room temperature, diluted with $\mathrm{CH}_{2} \mathrm{Cl}_{2}(8 \mathrm{~mL})$, stirred for $15 \mathrm{~min}$ and filtered. The filtrate containing the acid chloride 6 was collected and used in the next step directly. A saturated solution of methylamine was cooled to $0-5{ }^{\circ} \mathrm{C}$ and to this was added the $\mathrm{CH}_{2} \mathrm{Cl}_{2}$ solution of acid chloride 6 with stirring maintaining the temperature below $0{ }^{\circ} \mathrm{C}$. The reaction mixture was stirred at the same temperature for $0.5 \mathrm{~h}$ and then at room temperature for $3 \mathrm{~h}$. After completion of the reaction the mixture was filtered and the filtrate was collected and concentrated. The gummy residue obtained was stirred with cold water $(100-150 \mathrm{~mL})$ for $0.5 \mathrm{~h}$ and then filtered. The solid obtained was washed for several times with water, $20 \%$ ethyl acetate $/ n$-hexane and dried to give the title compound crude product ( $1.5 \mathrm{~g}, 38 \%$ yield) as a brown solid; mp $132-136{ }^{\circ} \mathrm{C} ; R_{\mathrm{f}}(60 \%$ ethyl acetate $/ n$-hexane $) 0.3 ;{ }^{1} \mathrm{H}$ NMR (DMSO- $\left.d_{6}, 400 \mathrm{MHz}\right) 8.17(\mathrm{~d}, J=8.4 \mathrm{~Hz}, 2 \mathrm{H}), 7.40$ (d, $J=8.4$ $\mathrm{Hz}, 2 \mathrm{H}), 4.12$ (bs, NH, 1H), 3.27-3.22 (m, $2 \mathrm{H}), 2.87-2.83$ (m, 2H), $2.70(\mathrm{~d}, J=4.5 \mathrm{~Hz}, 3 \mathrm{H})$; IR $\left(\mathrm{cm}^{-1}, \mathrm{KBr}\right) 3411,1312$, 1145; m/z (ES Mass) 245 (M+1, 100\%); ${ }^{13} \mathrm{C}$ NMR (DMSO- $d_{6}$, $50 \mathrm{MHz}) \delta 148.5,145.6,128.7$ (2C), 124.5 (2C), 58.5, 24.8, 24.4; HRMS (ESI): calcd for $\mathrm{C}_{9} \mathrm{H}_{13} \mathrm{~N}_{2} \mathrm{O}_{4} \mathrm{~S}(\mathrm{M}+\mathrm{H})^{+} 245.0595$, found 245.0592 .

Preparation of 2-(4-amino-phenyl)ethanesulfonic acid methylamide (8): A solution of compound 7 (1.55 g, $6.3 \mathrm{mmol})$ was dissolved in 1:1 methanol/ethyl acetate $(30 \mathrm{~mL})$ and hydrogen- 
ated in the presence of Raney nickel $(1.5 \mathrm{~g})$ at 65 to $70 \mathrm{psi}$ for 4-5 h. The reaction mixture was filtered through celite bed. The filtrate was collected, concentrated and dried to give the title compound ( $1.0 \mathrm{~g}, 74 \%$ yield) as a brown solid; mp $126-128{ }^{\circ} \mathrm{C}$; $R_{\mathrm{f}}\left(75 \%\right.$ ethyl acetate $/ n$-hexane) $0.3 ;{ }^{1} \mathrm{H}$ NMR (DMSO- $d_{6} 400$ MHz) $\delta 6.90(\mathrm{~d}, J=8.5 \mathrm{~Hz}, 2 \mathrm{H}), 6.88(\mathrm{bs}, \mathrm{NH}, 1 \mathrm{H}), 6.50(\mathrm{~d}, J=$ $8.2 \mathrm{~Hz}, 2 \mathrm{H}), 4.91$ (bs, NH, 2H), 3.17-3.12 (m, 2 H), 2.77-2.73 (m, 2H), $2.56(\mathrm{~d}, J=4.5 \mathrm{~Hz}, 3 \mathrm{H})$; IR $\left(\mathrm{KBr}, \mathrm{cm}^{-1}\right) 3411,1312$, 1145; m/z (ES Mass): 215 (M+1, 100\%); ${ }^{13} \mathrm{C}$ NMR (DMSO- $d_{6}$, $50 \mathrm{MHz}$ ): 146.9, 128.7 (2C), 125.2, 114.0 (2C), 51.0, 28.5, 28.3; HRMS (ESI): calcd for $\mathrm{C}_{9} \mathrm{H}_{15} \mathrm{~N}_{2} \mathrm{O}_{2} \mathrm{~S}(\mathrm{M}+\mathrm{H})^{+}$215.0854, found 215.0856 .

Preparation of 2-(4-amino-3-iodo-phenyl)ethanesulfonic acid methylamide (9): A suspension of compound 8 (1.0 g, 4.67 $\mathrm{mmol})$ in aqueous solution $(10.0 \mathrm{~mL})$ of sodium bicarbonate (4.67 mmol) was stirred for $0.5 \mathrm{~h}$. Then iodine $(4.20 \mathrm{mmol})$ was added at $5-10{ }^{\circ} \mathrm{C}$ and the mixture was stirred for $6.0 \mathrm{~h}$. After completion, the reaction mixture was diluted with ethyl acetate $(50 \mathrm{~mL})$ and extracted with ethyl acetate $(3 \times 50 \mathrm{~mL})$. The organic layers were collected, combined, washed with saturated aqueous sodium thiosulfate solution $(2 \times 25 \mathrm{~mL})$, dried over anhydrous $\mathrm{Na}_{2} \mathrm{SO}_{4}$ and concentrated under vacuum. The crude product was purified by column chromatography on silica gel using 7:3 hexane/ethyl acetate to afford the desired product ( $1.24 \mathrm{~g}, 78 \%$ yield); brown solid; $\mathrm{mp} 98-100{ }^{\circ} \mathrm{C} ; R_{\mathrm{f}}(60 \%$ ethyl acetate $/ n$-hexane) $0.3 ;{ }^{1} \mathrm{H} \mathrm{NMR}\left(\mathrm{CDCl}_{3}, 400 \mathrm{MHz}\right) \delta 7.41(\mathrm{~s}$, $1 \mathrm{H}), 6.98(\mathrm{~d}, J=8.0 \mathrm{~Hz}, 1 \mathrm{H}), 6.89$ (bs, NH, 1H), 6.69 (d, $J=$ $8.0 \mathrm{~Hz}, 1 \mathrm{H}), 5.06$ (bs, NH, 2H), 3.19-3.15 (m, $2 \mathrm{H}), 2.74-2.73$ (m, 2H), 2.58 (d, $J=4.5 \mathrm{~Hz}, 3 \mathrm{H})$; IR ( $\left.\mathrm{cm}^{-1}, \mathrm{KBr}\right) 3387,1499$, 1307, 1147; m/z (ES Mass) $341(\mathrm{M}+1,100 \%) ;{ }^{13} \mathrm{C} \mathrm{NMR}$ (DMSO- $\left.d_{6}, 200 \mathrm{MHz}\right): 146.8,137.8,129.1,128.0,114.2,83.1$, 50.6, 28.5, 27.6; HRMS (ESI): calcd for $\mathrm{C}_{9} \mathrm{H}_{14} \mathrm{~N}_{2} \mathrm{O}_{2} \mathrm{SI}(\mathrm{M}+\mathrm{H})^{+}$ 340.9821 , found 340.9824 .

Preparation of 2-(3-iodo-4-methanesulfonylaminophenyl)ethanesulfonic acid methylamide (10): A mixture of compound 9 (1.0 g, $2.94 \mathrm{mmol}$ ), DMAP (53.21 mg, $0.43 \mathrm{mmol}$ ) was dissolved in pyridine $(5.0 \mathrm{~mL})$ and cooled to $0-5{ }^{\circ} \mathrm{C}$. To this was added methanesulfonyl chloride $(3.82 \mathrm{mmol})$ dropwise and the mixture was refluxed for $12 \mathrm{~h}$. After completion of the reaction, the mixture was cooled to $5-10{ }^{\circ} \mathrm{C}$, neutralized with dil $\mathrm{HCl}$ and extracted with ethyl acetate $(3 \times 50 \mathrm{~mL})$. The organic layers were collected, combined, washed with saturated aq. $\mathrm{NaCl}(2 \times 25 \mathrm{~mL})$, dried over anhydrous $\mathrm{Na}_{2} \mathrm{SO}_{4}$ and concentrated under vacuum. The crude compound was purified by column chromatography on silica gel using $9: 1$ hexane/ethyl acetate to afford the desired product ( $1.0 \mathrm{~g}, 82 \%$ yield) as a brown solid, mp $156-158{ }^{\circ} \mathrm{C} ; R_{\mathrm{f}}(20 \%$ ethyl acetate $/ n$-hexane) $0.3 ;{ }^{1} \mathrm{H}$ NMR (DMSO- $\left.d_{6}, 400 \mathrm{MHz}\right) \delta 7.88(\mathrm{~s}, 1 \mathrm{H}), 7.40-7.34$ (m, 3H), 6.57 (bs, NH, 1H ), 3.26-3.23 (m, 2H), 3.21-3.02 (m,
2H), $2.81(\mathrm{~s}, 3 \mathrm{H}), 2.71(\mathrm{~d}, J=4.5 \mathrm{~Hz}, 3 \mathrm{H})$; IR $\left(\mathrm{cm}^{-1}, \mathrm{KBr}\right)$ 3276, 1476, 1364, 1156; m/z (ES Mass): $418(\mathrm{M}+1,100 \%) ;{ }^{13} \mathrm{C}$ NMR (DMSO- $\left.d_{6}, 200 \mathrm{MHz}\right): 142.8,140.1,135.0,131.7,129.6$, $104.0,49.5,43.8,28.5,28.1$; HRMS (ESI): calcd for $\mathrm{C}_{10} \mathrm{H}_{16} \mathrm{~N}_{2} \mathrm{O}_{4} \mathrm{~S}_{2} \mathrm{I}(\mathrm{M}+\mathrm{H})^{+} 418.9596$, found 418.9607 .

Preparation of 2-(1-methanesulfonyl-2-phenyl-1H-indol-5yl)ethanesulfonic acid methylamide (C): A mixture of 10 (1.0 g, $2.39 \mathrm{mmol}), 10 \% \mathrm{Pd} / \mathrm{C}$ (76.0 mg, $0.071 \mathrm{mmol}), \mathrm{PPh}_{3}(75.22$ $\mathrm{mg}, 0.28 \mathrm{mmol}), \mathrm{CuI}(27.4 \mathrm{mg}, 0.14 \mathrm{mmol})$ and 2-aminoethanol $(0.44 \mathrm{~g}, 7.17 \mathrm{mmol})$ in $\mathrm{H}_{2} \mathrm{O}(25 \mathrm{~mL})$ was stirred at $25^{\circ} \mathrm{C}$ for $1 \mathrm{~h}$ under nitrogen. The acetylenic compound $2 \mathrm{~g}(0.73 \mathrm{~g}$, $7.17 \mathrm{mmol}$ ) was added slowly to the mixture with stirring. The reaction mixture was then stirred at $80{ }^{\circ} \mathrm{C}$ for $12 \mathrm{~h}$. The mixture was cooled to room temperature, diluted with EtOAc $(250 \mathrm{~mL})$ and filtered through celite. The filtrate was collected, washed with cold water $(2 \times 125 \mathrm{~mL})$, dried over $\mathrm{Na}_{2} \mathrm{SO}_{4}$, filtered and concentrated under vacuum. The residue thus obtained was purified by column chromatography (hexane/EtOAc) to afford the desired product $(0.75 \mathrm{~g}, 80 \%$ yield $)$ as a brown solid, $\mathrm{mp}$ $150-152{ }^{\circ} \mathrm{C} ; R_{\mathrm{f}}\left(60 \%\right.$ ethyl acetate $/ n$-hexane) $0.3 ;{ }^{1} \mathrm{H}$ NMR $\left(\mathrm{DMSO}-d_{6}, 400 \mathrm{MHz}\right) \delta 7.89(\mathrm{~d}, J=8.2 \mathrm{~Hz}, 2 \mathrm{H}), 7.58-7.51(\mathrm{~m}$, $3 \mathrm{H}), 7.43-7.31(\mathrm{~m}, 3 \mathrm{H}), 6.99(\mathrm{bs}, \mathrm{NH}, 1 \mathrm{H}), 6.81(\mathrm{~s}, 1 \mathrm{H})$, $3.35-3.29(\mathrm{~m}, 2 \mathrm{H}), 3.08-3.04(\mathrm{~m}, 5 \mathrm{H}), 2.60$ (d, $J=4.8 \mathrm{~Hz}, 3 \mathrm{H})$; IR $\left(\mathrm{cm}^{-1}, \mathrm{KBr}\right) 3275,1363,1320,1173.6 ; \mathrm{m} / \mathrm{z}$ (ES Mass) 393 $(\mathrm{M}+1,100 \%) ;{ }^{13} \mathrm{C}$ NMR (DMSO- $\left.d_{6}, 200 \mathrm{MHz}\right) \delta 141.5,135.9$, 134.4, 131.9, 129.9, 129.8 (2C), 127.5 (2C), 125.3, 120.5, 115.0, 112.0, 59.7, 50.7, 38.6, 30.6, 20.7; HRMS (ESI): calcd for $\mathrm{C}_{18} \mathrm{H}_{21} \mathrm{~N}_{2} \mathrm{O}_{4} \mathrm{~S}_{2}(\mathrm{M}+\mathrm{H})^{+}$393.0943, found 393.0942.

\section{Supporting Information}

\section{Supporting Information File 1}

Spectral data of 2-substituted indoles 3a-s.

[http://www.beilstein-journals.org/bjoc/content/ supplementary/1860-5397-5-46-S1.doc]

\section{Acknowledgments}

The authors thank Dr. V. Dahanukar and Mr. A. Mukherjee for their encouragement and the analytical group of DRL for spectral data. Mr. M. L. thanks CPS-DRL, Hyderabad, India for allowing him to pursue this work as a part of his Ph.D. program.

\section{References}

1. Holenz, J.; Pauwels, P. J.; Díaz, J. L.; Mercè, R.; Codony, X.; Buschmann, H. Drug Discovery Today 2006, 11, 283-299. doi:10.1016/j.drudis.2006.02.004

(See for a review.) 
2. Riggs, J. R.; Kolesnikov, A.; Hendrix, J.; Young, W. B.; Shrader, W. D.; Vijaykumar, D.; Stephens, R.; Liu, L.; Pan, L.; Mordenti, J.; Green, M. J.; Sukbuntherng, J. Bioorg. Med. Chem. Lett. 2006, 16, 2224-2228. doi:10.1016/j.bmcl.2006.01.039

3. Kolesnikov, A.; Rai, R.; Young, W. B.; Mordenti, J.; Liu, L.; Torkelson, S.; Shrader, W. D.; Leahy, E. M.; Hu, H.; Gjerstad, E.; Janc, J.; Katz, B. A.; Sprengeler, P. A. Bioorg. Med. Chem. Lett. 2006, 16, 2243-2246. doi:10.1016/j.bmcl.2006.01.037

4. Sugimoto, Y.; Shimizu, A.; Kato, T.; Satoh, A.; Ozaki, S.; Ohta, H.; Okamoto, O. Bioorg. Med. Chem. Lett. 2006, 16, 3569-3573. doi:10.1016/j.bmcl.2006.03.086

5. Koppitz, M.; Reinhardt, G.; van Lingen, A. Tetrahedron Lett. 2005, 46, 911-914. doi:10.1016/j.tetlet.2004.12.058

6. Payack, J. F.; Vazquez, E.; Matty, L.; Kress, M. H.; McNamara, J. J. Org. Chem. 2005, 70, 175-178. doi:10.1021/jo048334k

7. Brands, M.; Ergüden, J.-K.; Hashimoto, K.; Heimbach, D.; Schröder, C.; Siegel, S.; Stasch, J.-P.; Weigand, S. Bioorg. Med. Chem. Lett. 2005, 15, 4201-4205. doi:10.1016/j.bmcl.2005.06.085

8. Russell, M. G. N.; Matassa, V. G.; Pengilley, R. R.; van Niel, M. B.; Sohal, B.; Watt, A. P.; Hitzel, L.; Beer, M. S.; Stanton, J. A.; Broughton, H. B.; Castro, J. L. J. Med. Chem. 1999, 42, 4981-5001. doi:10.1021/jm9910021

9. Humphrey, G. R.; Kuethe, J. T. Chem. Rev. 2006, 106, 2875-2911. doi:10.1021/cr0505270 (See for a review.)

10. Krüger, K.; Tillack, A.; Beller, M. Adv. Synth. Catal. 2008, 350, 2153-2167. doi:10.1002/adsc.200800409

11. Ackermann, L. Synlett 2007, 507-526. doi:10.1055/s-2007-970744

12. Joucla, L.; Djakovitch, L. Adv. Synth. Catal. 2009, 351, 673-714. doi:10.1002/adsc.200900059

13. Cacchi, S.; Fabrizi, G. Chem. Rev. 2005, 105, 2873-2920. doi:10.1021/cr040639b (See for a review.)

14. Pal, M.; Subramanian, V.; Batchu, V. R.; Dager, I. Synlett 2004, 1965-1969. doi:10.1055/s-2004-830861

15. Dains, F. B. Y.; Vaughan, T. H.; Janney, W. M. J. Am. Chem. Soc. 1918, 40, 931-936.

16. Rosauer, K. G.; Ogawa, A. K.; Willoughby, C. A.; Ellsworth, K. P.; Geissler, W. M.; Myers, R. W.; Deng, Q.; Chapman, K. T.; Harris, G.; Molle, D. E. Bioorg. Med. Chem. Lett. 2003, 13, 4385-4388. doi:10.1016/j.bmcl.2003.09.022

17. Stefano, S.; Claudio, F. Synlett 2005, 809-812. doi:10.1055/s-2005-863741

18. James, C. L.; James, J. F.; George, F. A.; Amy, M.; Do, W. H.; Zhihua, S. J. Bioorg. Med. Chem. Lett. 2006, 16, 5646-5649. doi:10.1016/j.bmcl.2006.07.020

\section{License and Terms}

This is an Open Access article under the terms of the Creative Commons Attribution License

(http://creativecommons.org/licenses/by/2.0), which permits unrestricted use, distribution, and reproduction in any medium, provided the original work is properly cited.

The license is subject to the Beilstein Journal of Organic Chemistry terms and conditions:

(http://www.beilstein-journals.org/bjoc)

The definitive version of this article is the electronic one which can be found at:

doi:10.3762/bjoc.5.46 